\title{
Legal Protection of Copyright and Patent Architectural Rights of Electrical Vehicles Battery Against Human Rights in Indonesia
}

\author{
Rahayu Subekti ${ }^{1, *}$, Hadhika Afghani Imansyah ${ }^{2, *}$, Mariano Adhyka Susetyo ${ }^{3}$ \\ ${ }^{1}$ Faculty of Law, Universitas Sebelas Maret Surakarta, Central Java, Indonesia \\ ${ }^{2}$ Faculty of Law, Universitas Sebelas Maret Surakarta, Central Java, Indonesia \\ ${ }^{3}$ Faculty of Law, Universitas Sebelas Maret Surakarta, Central Java, Indonesia \\ *Corresponding author.Email: rahayusuubekti0211@staff.uns.ac.id, hadhikaafghanii@gmail.com, \\ bernediktussuharyo@gmail.com
}

\begin{abstract}
This study was carried out to ascertain the type of intellectual property legal protection in terms of copyright and patent rights for architectural creators and inventions of electric vehicle battery technology based on Law Number 28 of 2014 , Law Number 13 of 2016, and other regulations. The research method used in this study is a normative juridical research method with a conceptual, statutory, and approach of case. The granting of copyright is based on declarative principles and its correlation to the legal object, namely the architectural design of electric vehicle batteries. Patent rights, on the other hand, are granted based on the principle of first to invent or first to file. This is contingent on the country adhering to the principles outlined in the regulations. In Indonesia, copyright and patent protection adheres to the declaratory and first to file principles but does not deny that the first to invent principle can be used at times. As for the ultimate purpose of this research is to ensure the guarantee of human rights for the creators and inventors of architectural designs and technology of electric vehicle battery in Indonesia.
\end{abstract}

Keywords: Copyright, Electric Vehicle Battery, Legal Protection, Patent.

\section{INTRODUCTION}

Every person has the right to adapt the state's rights and duties by incorporating them into regulations and legal structures under changing norms. As a result of the evolving framework of thinking, the constitution is the outcome of a collective agreement of all the people, which is the holder of the highest power based on the principle of popular sovereignty. This, of course, leads to the constitution's status as the highest law in the life of the country and state (the supreme law of the land). The constitution, which derives from the verb "to constitute," which meaning "to create," may also be regarded as a text that establishes state entities. As a result, the constitution binds all state components, both administrators and citizens.[1]
Legal protection is the defense of one's dignity and value, as well as the acknowledgment of human rights held by legal subjects, based on legal provisions of power or as a set of laws or regulations that can protect one object from another. [2] Legal protection in Indonesia is always founded on the 2nd Pancasila Precept and the 1945 Constitution specifically Article 28D paragraph (1), which declares that

"Everyone has the right to recognition, assurances, protection, and fair legal certainty, as well as equal treatment before the law."

In terms of real job recognition and guarantee, it must be assured by the state based on legislative rules.

Aspects of legal protection for humans include two basic things, namely protection from economic power and protection from government actions. Departing from 
this, the business actors of electric vehicle manufacturers in making a product certainly hope to get legal protection so that their production is not plagiarized by others. This legal protection is known as a patent. Patents are industrial property rights that are strung together in intellectual property rights. One example in the automotive world is the infringement of patents by Hyundai and KIA on the gasoline-electric hybrid technology by the Paice company. Departing from this case, the authors aim to ensure that the Central Government and Local Governments safeguard all forms of intellectual property rights, including technological and architectural inventions of electric cars.

\section{COPYRIGHT PROTECTION FOR ELECTRIC VEHICLE BATTERY ARCHITECTURAL DESIGN}

Law No. 6 of 1982 Concerning Copyright was Indonesia's first copyright regulation. Indonesia's involvement in the WTO and as one of the nations that have ratified TRIPs is a result of Indonesia's commitment to implementing the agreement and incorporating it into national legal rules. As a result, the laws and regulations governing copyright have undergone several changes in response to developments and needs, beginning with Law No. 7 of 1987, which was later refined by Law No. 12 of 1997, which was then refined again into Law No. 19 of 2002, and finally underwent improvements with Law No. 28 of 2014.

According to Article 1 point 1 of Law Number 28 of 2014, copyright is the creator's exclusive right that emerges naturally based on declaratory principles once work is manifested in a physical form without lowering limits in accordance with the requirements of laws and regulations. According to Article 1 point 3 of Law Number 28 of 2014, a creation is a person or a group of individuals who separately or together develop a one-ofa-kind and personal creation. Authenticity and concreteness must be met by protected works. [3].

Furthermore, Indonesian copyright law, copyright is exclusive right which consists of economic rights and moral rights. According to the article, copyright is an exclusive right, meaning that no one else is allowed to use that right because it belongs to the creator. If another party recognizes the right to economic benefits, that party must obtain the written authorization of the inventor and owner [4]

Copyright is "automatically created," which means it does not need to be registered like other types of intellectual property rights. This fundamental concept stems from the Berne agreement, which states that legal protection for a work is achieved by physical realization rather than registration. The core notion of copyright, however, does not exclude the inventor from registering his work. Although work registration is not required, it has proved helpful for creators in practice since it may be used as proof in disputes with other parties [5].

The regulation of moral rights stretches back to the nineteenth century in France, and its evolution is reflected in the 1928 Berne Convention Article 6 amendment, which states:

"Independently of author's economic rights, and even after the transfer of the said rights, the author shall have the right to claim authorship of the work and to abject to any distorstion, mutilation or other modification of, or other derogatory action relation to, the said work, would be prejudicial to his honour or reputation"

According to the article's formulation, the essence of moral rights includes: [6]

a. To claim authorship of the right, specifically, the right to be recognized as a creator.

b. The right to object to any distortion, mutilation or other modification of the work, specifically, the creator's right to refuse acts that distort, cut, or remove a piece of the work or change the work in such a way that the creator's name and honor are harmed.

c. The right to object other derogatory action in relation to the sain work, specifically, the creator's right to refuse any action or treatment that may disrupt or degrade the creator's dignity and reputation.

Moral rights, as defined in Article 4, are rights that are inextricably linked to the creator:

a. In conjunction with the public usage of his invention, he may still include or exclude his name from the copy.

b. Using a pen name or alias

c. Changing the creation to conform to social norms

d. Changing the creation's title and subtitle, and

e. Defending his rights in the case of a work distortion, mutilation, alteration, or anything else that is damaging to his honor or reputation.

None of these rights can be transmitted while the creator is still alive, save by the creator's will according to statutory regulations. Even if the economic rights of the copyright have been sold or passed to other persons, this moral right remains to follow and is connected to the author. [7] The moral rights of the creator demonstrate the strong link that exists between a creator and his created. [8]

This is included in copyright in the architectural design of electric vehicle batteries since the object of the copyright is one of the images. So, as long as the inventor 
creates and announces his work in the form of an architectural design drawing of the battery, it is lawful and regarded his work. As a result, if another party makes use of an architectural design, the design maker may seek royalties from that party.

\section{PATENT PROTECTION FOR INVENTIONS IN ELETRIC VEHICLE BATTERY TECHNOLOGY}

Exclusive rights of patent is provided to inventors by the state for their innovations in the technology for a specific length of time to carry out their ideas or give approval to third parties to execute them, according to Indonesia Patent Law. [9] Patents provide not only protection against technological inventions, but also exclusive rights attached to the owner or holder of the patent right, such that if another party receiving the transfer wishes to obtain economic benefits from using the patent, it must obtain a license (permit) from the owner or holder [10]. Based on this, the state classifies patents as exclusive rights since they play a strategic and significant role in furthering growth for the benefit of the community. Furthermore, the Patent Law in Indonesia not only offers legal protection for national patents, but also for international nationals whose registration is carried out on Indonesian territory.

According to Patent Law, a patent is given for a new invention if it comprises creative steps and may be implemented in industry, whereas a simple patent is awarded for a new invention, development of an existing product or method, and can be applied in industry. [11] In this law, an invention is considered new if it is not the same as previously disclosed technology on the date of receipt, provided that the technology in question has been announced in Indonesia or outside Indonesia in a written, description of oral, or demonstration to implement before the date of acceptance or priority date.

Regarding simple patents in TRIPs, they are not specifically regulated. TRIPs only contain minimum provisions that must be followed by member countries. This means that they can apply broader provisions, as long as they comply with the provisions of the TRIPs themselves and the principles of international law. [12] This is in accordance with the provisions of TRIPs in article 27 as follows:

"Patent shall be available for any inventions, whether products or processes, in all fields of technology, provided that the are new, involve an inventive step and are capable of industrial apliction. And patent shall be available and patent right enjoyable without discrimination as to be place of invention, the field of technology and whether products an imported or locally produced'. [13]

According to this article, the state should typically award patent rights based on an innovation application.
In the case of a patent application, there is a distinction between a patent application letter and an patent application. It has its own document and is known as a "request of patent," whereas a patent application is known as a "patent application" and comprises a full document indicating the date of receipt of the patent application document (filling date).

A simple patent application must be filed by the inventor or the person entitled to the invention, together with a fee. If the application is not submitted by the inventor, it must be accompanied by a declaration followed by proof indicating the rights of the person filing the patent application on the invention for which the patent is sought.

According to patent law, the first applicant is to be awarded a patent by a nation, however this does not necessarily apply to another country that uses the first to invent rule or principle. However, both the first to file and first to invent principles do not rule out the potential of similarities to innovations or ideas that have been patented. Because a new invention can be awarded a patent only on the basis of the scope of protection in issue, as long as the results of the invention have nothing in common with those already registered under the principle of first to file or first to invent. Regarding inventions, one of which is for electric car batteries, if the right is patented in Indonesia, patents law govern the duration of patent protection, meaning the patent rights has a period of 20 years from the receipt date and cannot renewed are only granted for 20 years from the date of stipulation and cannot be extended. The beginning and ending dates of patent rights are documented and communicated in electronic and/or non-electronic means. As for simple patents have a 10 -year validity duration from the date of receipt and cannot be extended. A simple patent's start and termination dates are publicized by electronic and/or non-electronic means. [14]

An electric vehicle is powered by an electric motor and runs on electrical energy stored in batteries. [15] Many electric car batteries are still under development and have not yet been patented. This is the case for Local Transportation Based on Hybrid-Electric Vehicles (HEVs) with the design of Electric Vehicles Based Continuous Variable Transmission (EV-CVT) to enhance the carrying capacity of urban transportation in a pilot project at Ganesha Education University. Whereas the government has encouraged the development of electric cars in Indonesia through Indonesia Presidential Regulation about the Acceleration of the Battery Electric Vehicle Program. [16]

The Litbangjirap Institute, on the other hand, is a research institute that is doing a study on the first rapid charging battery in Indonesia. Since 2018, the development of technologies connected to SPKLU (generic electric vehicle battery charging station) or CS (charging station) has been carried out. Of course, when 
it comes to patent law, the research and development of this technology falls under the category of Simple Patents. Of course, patent protection for ideas resulting from the development of electric car batteries may benefit inventors in terms of economic and legal protection, as well as allow the public to enjoy the advantages of these discoveries safely and legally.

\section{CONCLUSION}

Whereas in Indonesia, copyright protection in electric vehicle architecture for human rights has been regulated in copyright law which states that copyright is the exclusive right of the creator that arises naturally based on declarative principles when a work is realized in physical form without reduce restrictions. in accordance with the requirements of the legislation. In terms of architectural electric car technology, the author already has the copyright in accordance with the provisions of the laws and regulations in effect in Indonesia when the work was originally made and published in accordance with declaratory principles.

Patents are exclusive rights granted by the state to inventors for their innovations in the field of technology for a specific length of time, either to carry out their ideas or to provide permission to third parties to execute them. In the case of electric vehicle batteries, the development of battery-related topics can be patented based on the technological object in the battery under development. For example, the Litbangjirap Institute has been developing technologies related to SPKLU (generic electric vehicle battery charging station) or CS (charging station) since 2018. Thus, the human rights of the creator of electric vehicle architectural design and the inventor of electric vehicle battery technology have guaranteed by the laws, both moral rights, economic rights and other rights attached to the creation.

\section{REFERENCES}

[1] T. Brian, Textbook on Constitutional and Administrative Law, (London: Black Stone Press Ltd, 1997), h.3

[2] M. H. Philipus, Perlindungan Hukum Bagi Masyarakat Indonesia, (Surabaya; Bina Ilmu, 1983), h. 38

[3] Sudartat, dkk, Hak Kekayaan Intelektual, (Bandung: Oase Media), h. 19

[4] D. Muhammad dan R. Djubaedilah, Hak Milik Intelektual, Sejarah, Teori dan Prakteknya di Indonesia (Bandung: Citra Adity Bakti, 1994) h. 68

[5] S. U. Tomi, Hak Kekayaan Intelektual di Era Global, Sebuah Kajian Kontemporer (Yogyakarta: Graha Ilmu, 2010) h. 71
[6] S. Henry, Hak Cipta Tanpa Hak Moral, (Jakarta: Rajagrafindo Persada, 2011) h. 105

[7] U. Rachmadi, Hukum Hak atas Kekayaan Intelektual, (Bandung: Alumni, 2003) h.112

[8] JCT. Simorangkir, Hak Cipta Lanjutan, (Jakarta: Djembatan, 1979) h. 37

[9] Undang-Undang Republik Indonesia Nomor 13 Tahun 2016 tentang Paten

[10] Syafrida, Pentingnya Perlindungan Hukum Paten Warga Negara Asing di Wilayah Indonesia Guna Meningkatkan Investasi Asing, Jurnal Hukum ADIL, Vol.10, No (01), 2019, h. 93-110

[11] Undang-Undang Republik Indonesia Nomor 13 Tahun 2016 tentang Paten

[12] A. Z. U. Purba, Hak Kekayaan Intelektual Pasca TRIPs (Bandung: PT Alumni, 2005), Cetakan I, h. 24

[13] Trade-Related of Intellectual Property Rights (TRIPs), Art. 27

[14] D. Muhammad dan Djubaidillah, Hak Milik Intelektual Sejarah, Teori dan Prakteknya di Indonesia, (Bandung: Citra Aditya Bakti, 2003) h. 183

[15] M. Fuady, Pengantar Hukum Bisnis, (Bandung: Citra Adtya Bakti, 2002), hlm. 207

[16] L. S. Djaman, 2019, - Peraturan Presiden Republik Indonesia Nomor 55 Tahun 2019 